\title{
THE MANAGERIALIZATION OF REFUGEE DETERMINATIONS IN CANADA
}

\author{
Dagmar Soennecken
}

Ed. juridiques associées | « Droit et société »

2013/2 n $84 \mid$ pages 291 à 311

ISSN 0769-3362

ISBN 9782275028781

Article disponible en ligne à l'adresse :

http://www.cairn.info/revue-droit-et-societe-2013-2-page-291.htm

\section{!Pour citer cet article :}

Dagmar Soennecken, « The Managerialization of Refugee Determinations in Canada », Droit et société 2013/2 ( $\left.{ }^{\circ} 84\right)$, p. 291-311.

Distribution électronique Cairn.info pour Ed. juridiques associées.

(C) Ed. juridiques associées. Tous droits réservés pour tous pays.

La reproduction ou représentation de cet article, notamment par photocopie, n'est autorisée que dans les limites des conditions générales d'utilisation du site ou, le cas échéant, des conditions générales de la licence souscrite par votre établissement. Toute autre reproduction ou représentation, en tout ou partie, sous quelque forme et de quelque manière que ce soit, est interdite sauf accord préalable et écrit de l'éditeur, en dehors des cas prévus par la législation en vigueur en France. Il est précisé que son stockage dans une base de données est également interdit. 


\title{
The Managerialization of Refugee Determinations in Canada
}

\author{
Dagmar Soennecken
}

School of Public Policy \& Administration, York University, 136 McLaughlin College. 4700 Keele Street, Toronto, Ontario, M3J 1P3, Canada.

<dsoennec@yorku.ca>

Résumé La managérialisation du processus de détermination du statut de réfugié au Canada

Bien que les réfugiés soient protégés par une myriade de normes juridiques, cet article montre que le processus interne visant à déterminer qui obtient le statut de réfugié est devenu de plus en plus managérialisé et ce, même dans un pays comme le Canada, qui a généralement été considéré comme un chef de file parmi les pays accueillant des réfugiés. Cette préférence pour des critères fondés sur l'efficacité a graduellement mis à l'écart une précédente volonté de judiciariser les procédures d'attribution du statut de réfugié, dans la mesure où l'accès aux tribunaux pour les réfugiés est désormais généralement considéré comme problématique, voire suspect. Cet article utilise des outils institutionnels historiques pour mettre en lumière le rôle critique que l'environnement politique externe a joué dans la managérialisation graduelle des procédures de détermination du statut de réfugié.

Canada - Détermination du statut de réfugié - Droits légaux - Managérialisation.

Summary Although refugees are protected by a myriad of legal norms, this article shows that the domestic process of determining who is awarded this status has become more and more managerialized, even in a country like Canada, which has generally been considered a leader among refugee-receiving countries. This privileging of efficiency-based standards has gradually sidelined an earlier push to judicialize refugee determination procedures to the extent that access to the courts for refugees more generally is now considered problematic and ultimately suspect. The article uses historic institutional tools to highlight the critical role that the external, political environment has played in gradually managerializing refugee determination procedures.

Canada-Legal rights - Managerialization-Refugee determinations. 


\section{Introduction}

The managerialization of law has become a critical concept for our understanding of the interplay of law and managerialism, be that in private or in public organizations. Lauren Edelman's oeuvre of work on the subject in particular, has shown that externally created laws do not simply inform organizational practice from the outside. Since law is culturally and structurally rooted, organizational structures and ideas (not to mention managerial professionals) can actively shape and reconstruct law itself, at times with ambiguous outcomes for organizational practice. Edelman calls this phenomenon the "endogeneity of law". ${ }^{1}$ More specifically, she refers to the symbiosis of organizational ideas (chiefly, managerial notions of efficiency, rationality and profit) with ideational notions of justice and fairness as the "managerialization" of law. ${ }^{2}$ Her contributions constitute a body of scholarship that offers a nuanced portrayal of "law-in-action", underlining a classic message of law and society scholarship - that "lived" law, when closely observed, is much more complex, multi-faceted and at times contradictory than the "law-on-the-books" might suggest. 3

While much of L. Edelman's work, and that of others, has focused on analyzing the gradual, almost organic process of "seeping in" of managerial ideas into legal ideas, resulting in a subtle managerialization of law from within, this article examines an instance of managerialization from without ${ }^{4}$ - that is, the explicit introduction of key managerial ideas into a highly contested area of Canadian public administration, refugee determinations - along with the prior debate about, and subsequent revisions to, these ideas. In particular, I will focus on the critical role that shifting notions of efficiency - perhaps the central managerial idea - have played in sidelining the judicialization of refugee determination in Canada, one of the top refugee receiving countries among advanced industrial societies. 5 "Judicialization" here refers to a process that involves a shift toward procedures governed by judicial or quasi-judicial norms and an expansion of the role of the judiciary in reviewing refugee determinations. My analysis uses historic institutionalist tools to highlight the critical role that the external, political environment has played in gradually managerializing refugee determination procedures to the extent that now talk of "streamlining" 6 refugee determinations dominates the political debate in Canada

1. Lauren Edelman, “The Legal Lives of Private Organizations”, in Austin SARAT (ed.), The Blackwell Companion to Law and Society, Malden (MA): Blackwell, 2004, p. 238.

2. Ibid., p. 241.

3. Kitty CALAVITA, Invitation to Law \& Society, Chicago (IL): University of Chicago, 2010, p. 94.

4. The "within/without" distinction is inspired by Torbjörn VALLINDER, "When the Courts Go Marching In", in C. Neal TATE and Torbjörn VALLINDER (eds.), The Global Expansion of Judicial Power, New York: New York University Press, 1995, p. 14-16.

5. For 2010 and 2011, Canada was the $8^{\text {th }}$ largest refugee receiving country among industrialized societies (this represents 6 percent of all applications received). For year-by-year data, see the many publications under <www.unhcr.org $>$.

6. The word "streamlining" is repeatedly used in many government press releases, among others, over the years. 
to such an extent that access to the courts for refugees more generally has become problematic and even suspect from the perspective of both the government and the refugees. I rely largely on government documents and previously unexamined Parliamentary records to make my case.

More specifically, I argue that the managerialization of the Immigration and Refugee Board ("IRB"), the administrative agency responsible for refugee determinations since its founding in 1989 (and currently the largest administrative tribunal in Canada), is more than the outcome of a "natural", organizational symbiosis of managerial and legal ideas. It was fuelled by repeated government reform efforts aimed at retaining discretionary control over the process (and ultimately over who gets in), which eventually privileged efficiency and administrative convenience over fairness. As we shall see, the gradual decoupling of efficiency from notions of fairness and its eventual elevation played an important role in changing the perceptions of Canada's refugee determination procedures and lead to a growing aversion to granting refugees access to the courts or a judicialized procedure.

By analyzing the decades before and after the creation of the Immigration and Refugee Board (IRB), I show that managerial and legal ideals on refugee determination in Canada were not always at odds with one another. Yet after a brief confluence of the two in the mid 1960s, both political and bureaucratic actors increasingly referenced efficiency over effectiveness, thus eventually sidelining further attempts at judicialization. Theses references to efficiency further predate the rise of "New Public Management" techniques (NPM) in Canada, although they did proliferate after its introduction in the 1990s. Moreover, while experts have argued that for many decades, immigration policy decisions in Canada were not driven by partisan politics, 7 the current reforms aimed at "streamlining" the refugee determination process in Canada are more openly driven by a neoliberal (partisan political) agenda. 8

As L. Edelman notes: "The managerialization of law ... powerfully affects which actions or policies appear proper and which are injurious; it promotes certain types of claims and certain framings of legal issues while discouraging others. 9" Historic institutionalists would add that timing and sequencing is critical in determining which actions or policies rise to prominence. ${ }^{10}$ However, past choices can also have unintended consequences. ${ }^{11}$ My analysis reveals that the managerialization of refugee determination has been a slow-moving process during which legal ideas have become gradually separated from managerial ones to the extent that any calls for judicialization are currently viewed as further contributing to a "broken" refugee determi-

7. Yasmeen ABU-LABAN, "Welcome/Stay Out: The Contradiction of Canadian Integration and Immigration Policies at the Millennium”, Canadian Ethnic Studies, 20, 1998, p. 190-211.

8. For more, see Hélène Pellerin, "Economic Integration and Security: New Key Factors in Managing International Migration”, IRPP: Choices, 10, 2004, p. 4-26.

9. Lauren EdELMAN, “The Legal Lives of Private Organizations”, op. cit., p. 243.

10. Paul PIERSON, Politics in Time: History, Institutions and Social Analysis, Princeton (NJ): Princeton University Press, 2004.

11. See Robert C. Lieberman, "Ideas, Institutions, and Political Order: Explaining Political Change”, American Political Science Review, 96, 2002, p. 697-712. 
nation system that is "slow, inefficient, and attracts fraudulent/bogus claims", 12 underlining Edelman's argument, that legal ideas can indeed become disassociated from organizational goals in the managerialization process. 13

This article is divided into three parts. The first briefly discusses Canada's current approach to refugee protection as one element in its larger immigration policy before surveying the politics of efficiency in Canadian public administration both more generally and as it relates to refugee determinations. The second part analyzes the critical decades before and after the creation of the IRB in 1989. The discussion proceeds in chronological order. This overview is not intended to be a comprehensive examination of all of the issues pertaining to the IRB or refugee determination in Canada - it will focus predominantly on the push and pull between judicialization and managerialization. The third part contains the conclusion.

\section{Two Opposing Trends? New Public Management vs Judicialization and the IRB}

Anglo-American government bureaucracies hold particular promise for porting the study of the managerialization of law to the study of government and public administration because they all underwent similar waves of explicit managerialization through the "new public management" movement (NPM) from the late 1970s onward. Prominent advocates of NPM ideas range from Thatcher in the UK to Reagan in the US and Mulroney in Canada. NPM famously promised to "reinvent government", 14 which essentially meant to make the government more businesslike in its administrative practices. Its proponents assume that government, because of its monopoly situation, is "lethargic, cautious, bloated, expensive, unresponsive, a creature of routine and incapable of accepting new challenges" 15 and that the necessary fixes can be found by incorporating private sector, "entrepreneurial" management practices into government decision-making - chief among them the decentralization of control over, and empowerment of, subordinates, the establishment of measurable goals and results, achieved using the least time and resources. ${ }^{16}$ As Janice Stein observes: "Efficiency is often a code word for an attack on the ... sclerotic, unresponsive and anachronistic state, the detritus of our industrial age, which fits poorly with our times. 17"

As a consequence, many critics have noted that frequently, traditional standards of effectiveness and accountability, chief among them the principles of responsible government and due process, were sacrificed in the name of performance, which is narrowly defined as cost-effectiveness, productivity and responsiveness to "cli-

12. This is a summary of all the adjectives typically used in this context. More examples later.

13. Lauren EDELMAN, Sally Riggs Fuller and Iona MARA-DritA, "Diversity Rhetoric and the Managerialization of Law”, American Journal of Sociology, 106, 2001, p. 1599.

14. David Osborne and Ted GAEBlER, Reinventing Government, Reading (MA): Addison-Wesley, 1992.

15. Donald SAvore, "What Is Wrong with the New Public Management", Canadian Public Administration, 38, 1995, p. 114.

16. Office of the Auditor General CANAdA, "Efficiency in Government: A Special Study", in 1990 Report of the Auditor General of Canada, Ottawa: Auditor General of Canada, 1990.

17. Janice SteIn, The Cult of Efficiency, Toronto: House of Anansi Press, 2002, p. 6-7. 
ents". ${ }^{18}$ At the same time as NPM began to transform many government bureaucracies, efficiency, as Stein has prominently argued, was also elevated to "cult" status in society more generally. By obfuscating its older, historical origins (i.e. its connection with the industrial revolution) and newer alliances (in particular its affinity to a neoliberal agenda that emphasizes deficit reduction, small government and selfreliance among others), efficiency, J. Stein critically notes, became an end in itself, with little or no attention being paid to scale or to the greater values and goals that should underlie public policy making and larger societal debates. ${ }^{19}$ In short, in elevating efficiency, other effective modes of governance may be ignored because they are not necessarily the cheapest or the fastest. While J. Stein is particularly critical of the dearth of political debate around values and goals as well as the culture of choice that is emerging alongside this cult of efficiency, L. Edelman similarly urges us to "uncover the social values and political interests at stake in notions of rationality and efficiency", 20 a suggestion that I will return to later.

While one part of society began to value efficiency above anything else, at the same time, another began to speak predominantly in the language of rights. From the 1970s onward, a "rights revolution" swept Canada and other advanced industrialized societies. ${ }^{21}$ Similarly, as one part of government was becoming managerialized, another was becoming more and more judicialized. A "due process explosion" 22 saw the creation of numerous boards and agencies with various degrees of independence and court-like procedures that came to oversee key aspects of the regulatory state, from labour relations to human rights and refugee determinations. ${ }^{23}$ Although initially conceived as more efficient (i.e. less formal and less costly) alternatives to the courts, their proliferation brought with it such an expansion of due process norms that some critics began to speak of "over-judicialization". 24 As David Mullan, a well-known Canadian administrative law expert put it: "in many instances, judicialization [of administrative procedures] can significantly impede the effective and efficient management of mandates and severely tax already limited resources." 25 These remarks make it clear that judicialization and "efficient" management of administrative procedures (however defined) are seen as opposing and potentially clashing developments. The most efficient process many not be the

18. Gregory J. Inwood, Understanding Canadian Public Administration, Toronto: Prentice Hall, 1999, p. 362-363.

19. Janice STEIN, The Cult of Efficiency, op. cit., p. 7.

20. Lauren Edelman, "Rivers of Law and Contested Terrain: A Law and Society Approach to Economic Rationality”, Law \& Society Review, 38 (2), 2004, citing Tanina Rostain, p. 193.

21. Mary-Ann Glendon, Rights Talk: The Impoverishment of Political Discourse, New York: Free Press, 1991, Charles R. EPP, The Rights Revolution: Lawyers, Activists, and Supreme Courts in Comparative Perspective, Chicago: University of Chicago Press, 1998.

22. David Mullan, “Tribunals Imitating Courts. Foolish Flattery or Sound Policy”, Dalhousie Law Journal, 28, 2005, p. 1-26.

23. W. A. Bogart, Courts and Country: The Limits of Litigation and the Social and Political Life of Canada, Toronto: Oxford University Press, 1994, p. 107-133.

24. David MulLAN, “Tribunals Imitating Courts. Foolish Flattery or Sound Policy”, op. cit., p. 3.

25. Ibid., p. 16. 
most effective i.e. the most "just". Upholding certain standards of justice and fairness may cost more (or take longer) than is politically desirable.

The IRB has been at the heart of this clash. It has perhaps become the most publicly discussed example of a perceived "judicialization gone wrong". Although initially hailed as "fair and efficient" 26 by a prominent columnist in Canada's national newspaper, The Globe and Mail, after its creation in 1989, because it made decisions more quickly than its predecessor and deterred "bogus" claimants, within the following years, the opinion changed. It now was seen as the "creaky, leaky and appeal-layered refugee-determination system, with its two-year backlogs, high acceptance rates and possibilities for refugees vanishing into the underground economy or slipping into the United States". 27 The Supreme Court of Canada, which, through the Singh case in 1985, pushed judicialization along by declaring the previous refugee determination procedure (that did not contain an oral hearing component) unconstitutional, is also regularly blamed for this "over" judicialization. ${ }^{28}$ Not everyone agrees with this assessment, of course. Refugee advocates, although also not entirely content with the IRB either (in particular the training and appointment of its members), have repeatedly reminded the government that in its quest for control, efficiency and deterrence, it is sacrificing alternative reforms that other experts consider leading to good, reliable and fair decision-making. ${ }^{29}$ But before we can further delve into this debate, we need to briefly outline the IRB's functioning, its connection to the legal system, and its place in Canada's larger immigration policy.

Canada is a nation of immigrants. While the bulk of its immigrants are selected based on points given for a desired skill set in the economic category, refugees are assessed under the humanitarian category. Canada today also budgets for the arrival of refugees in an annual immigration plan presented to Parliament. 30 Of the roughly 250,000 immigrants expected to land in Canada each year, around 25,000 are refugees and their families. Of those 25,000, about half are expected to land in Canada uninvited; the other half are selected by Canadian officials from overseas refugee camps, largely in conjunction with United Nations High Commissioner for Refugees (UNHCR). There are also a variety of other humanitarian programs, e.g. ways for a church to sponsor refugees overseas or to help women at risk. Refugees selected overseas are not generally politically controversial. The unwanted refugees are those who arrive at a country's border uninvited, claiming protection. They are

26. Jeffrey SimPSON, “For True Refugees Only”, The Globe and Mail, April 15 1989, p. D6.

27. ID., "Refugee System Costs More Than We Think", The Globe and Mail, Jan. 7 2004, p. A17.

28. See for instance Jeffrey SIMPSON, "The Supreme Court Has Gummed up the Refugee Process", Globe and Mail, Feb 13 1997, p. A22. His column is characteristic of a persistent national coverage and perception. Singh $v$. Minister of Employment \& Immigration, [1985] 1 SCR 177.

29. For a recent example, see Peter SHOWLER, Fast, Fair and Final: Reforming Canada's Refugee System, Toronto: The Maytree Foundation, 2009. Showler is a former IRB Chairperson. The proposal contains a number of suggestions for best practices, including ideal timelines.

30. The Minister of Immigration is required to report annually to Parliament on immigration. 
the ones who are considered "the most unlike us" 31 and whose claims for protection are assessed by the IRB.

The IRB then conducts "first instance" refugee status determinations. It also oversees a number of other immigration-related matters. Refugees are only granted a hearing if they are first deemed eligible by a border agent. The IRB process consists of an oral hearing that is officially non-adversarial and follows quasi-judicial procedures (e.g. rules of procedure and evidence that are more "relaxed" than those in a full-fledged court), conducted by independently appointed members, ${ }^{32}$ selected from a range of professions. It is aimed at confirming the identity of the claimant and at assessing the credibility of their story of flight. IRB members are assisted by a (civil servant) Refugee Protection Officer, who does not "prosecute", but rather helps, with case preparation and questioning. 33 Frequently, lawyers and translators are also present. It thus fulfills immigration related functions but is independent from Citizenship and Immigration Canada, the respective government ministry. Its Chairperson reports directly to Parliament.

Since its founding in 1989, the IRB has become Canada's largest administrative tribunal. Along with it, the supervising court, the Federal Court of Canada, has grown as well. However, the way into the court is difficult - there is no automatic appeal of an IRB decision. Instead, one must apply for judicial review of the decision, which is more limited in nature. ${ }^{34}$ Regardless, more than half of the Court's business is now taken up by immigration proceedings, with refugee cases accounting for the "vast majority" of the Court's leave to appeal proceedings. 35

The Supreme Court of Canada, Canada's highest court, rarely hears issues involving immigrants and refugees. Still, it has crafted a number of decisions that are important to refugees, including the 1985 Singh case that (as we will see later) mandated oral hearings for refugee claimants. ${ }^{36}$ A 1992 Supreme Court of Canada (SCC) decision, Ward, 37 now constitutes the basis for many claims for protection. In Ward the Supreme Court followed the UNHCR recommendations, holding that a state need not be complicit in the persecution of the refugee. The fear of persecution has to be well founded, but for the individual to be protected under international law that fear need not be of the state directly; it can be of subordinate state

31. Catherine DAUVERgne, Humanitarianism, Identity and Nation: Migration Laws of Canada and Australia, Vancouver: UBC Press, 2005, p. 81.

32. These are political ("Governor in Council”) appointees. Recently, studies detailing drastic variations in acceptance rates among members have made headlines. See Sean REHAAG, "Troubling Patterns in Canadian Refugee Adjudication", Ottawa Law Review, 39, 2008, p. 335-365.

33. Catherine Dauvergne, Humanitarianism, Identity and Nation: Migration Laws of Canada and Australia, op. cit., p. 98 .

34. Decisions of Canadian government agencies are generally protected against judicial review as long as their decisions are considered fundamentally sound. "Sound" can either mean "correct" or "reasonable" in law. Applying a "correctness" standard triggers a more invasive review than a "reasonableness" standard.

35. For statistics, see <http://cas-ncr-nter03.cas-satj.gc.ca/portal/page/portal/CAS/AR-RA_eng>.

36. The Supreme Court has been such a rare commentator not because it has been unwilling to hear immigration and refugee cases, but because it is very difficult to get cases to proceed past numerous procedural hurdles at the Federal Court. There is also a leave to appeal procedure before the Supreme Court.

37. Canada (Attorney General) v. Ward, [1993] 2 SCR 689. 
authorities or of persons not attached to the state if the state is unable or unwilling to protect the individual from persecution.

Cases such as Ward have been important to the judicialization of refugee determination procedures because they flesh out and interpret refugee law. However, a number of court cases that arose after the entrenchment of the 1982 Charter, Canada's constitutional Bill of Rights, 38 have also been important to the judicialization of determination procedures because they have reinforced or elaborated on procedural standards. In Deghani, for instance, the Court found that refugee claimants could not be considered detained during the (now defunct) credible hearing stage at the border; therefore they do not have a right to counsel at that point. Here, the Court referred to Canada's right as a sovereign state to determine who enters its boundaries. ${ }^{39}$ In Pushpanthan, the Court for the first time commented on the standard of review that the Federal Court should apply to IRB decisions, arguing that the serious nature of the decision warranted the Federal Court to review the board's decision on its "correctness" and not merely on its "patent unreasonableness". 40

All in all, Canada has been quite generous in interpreting the Geneva Convention's refugee definition, though most domestic critics point out that recognition rates in Canada have declined significantly since the late 1980s. Still, according to the UNHCR, "first-instance" recognition rates globally are around 30 percent; while Canada's average recognition rate has hovered fairly consistently between 40 to 50 percent since 1996. ${ }^{41}$

Unfortunately, refugees - regardless of whether they meet the Geneva Convention definition at the outset or not - are increasingly viewed by the Canadian public and by political decision makers as queue jumpers who are resorting to devious means "to move from a poor country to a rich country", as immigration critic Daniel Stoffman put it. 42 Critics, such as D. Stoffman, do not view access to due process (including to a substantive appeal) as a genuine entitlement. In their view, it amounts to Canada being duped. What is worse, in the wake of $9 / 11$, refugees and refugee claimants are increasingly portrayed as criminals or as threats to national security, particularly since most of the individuals held in detention on grounds of national security (under "security certificates") either entered Canada as refugee claimants or were actually recognized by the IRB as Convention refugees before being detained. 43

\footnotetext{
38. 1982 Constitution Act, Part 1, "Canadian Charter of Rights and Freedoms", hereafter "the Charter".

39. Dehghani $v$. Canada (Minister of Employment and Immigration) [1993] 1 SCR 1053.

40. Pushpanathan v. Canada (Minister of Citizenship and Immigration) [1998] 1 SCR 982.

41. For Canadian data from 1989 to 2001 see Benjamin R. Dolin and Margaret Young, Canada's Refugee Protection System, Ottawa: Library of Parliament, Law and Government Division, October 2002, appendix 1. More recent data is available online from the IRB. For an overview, see UNHCR's website, for instance UNHCR Global Trends 2011 at <http://www.unhcr.org/pages/49c3646c4d6.html>.

42. Daniel Stoffman, Who Gets In: What's Wrong with Canada's Immigration Program - and How to Fix It, Toronto: Macfarlane Walter and Ross, 2002, p. 153.

43. The criminalization and securitization of refugee claimants is not new. See Audrey MACKLIN, "Borderline Security”, in Ronald J. DANIEls, Patrick MACKLEM, and Kent ROACH (eds.), The Security of Freedom: Essays on Canada's Anti-Terrorism Bill, Toronto: University of Toronto Press, 2001, p. 383-404.
} 


\section{What Kind of Process is Just vs Efficient? And Who Decides?}

As the preceding discussion already implied, despite an increasing politicization, refugees remain protected by a number of legal norms at both the international and domestic level. One could therefore easily imagine that managerial ideals, chief among them efficiency, would largely be subordinate to upholding legal notions of justice and fairness in refugee determinations. However, the large numbers of refugees flowing into some countries over others 44 already suggest that the assessment of all of these claims for protection can be daunting and requires balancing fairness with swift processing.

Interestingly, under international law, states retain responsibility for crafting procedures to assess these inland refugee claims. ${ }^{45}$ As a result, a wide range of procedures exists across advanced industrialized states. Furthermore, as we will see shortly, because its domestic refugee determination procedures have grown out of its larger, selectionist approach to immigration, Canada has retained a strong legacy of ministerial discretion, which has traditionally been a tool for controlling who gets into the country. Prior to the 1960s, who got in reflected a clearly racialized image of the Canadian nation, albeit with a humanitarian touch. ${ }^{46}$ Hence, it is in the detailed interpretation of the various legal norms and in the creation of particular types of refugee determination procedures where a state's interest (more specifically, its desire for control over who gets in) clashes with a growing international human rights regime and other domestic legal protections awarded to refugees. In the following, I want to suggest that the managerialization of refugee determinations is a reflection of this larger clash. But before turning to the examination of the development of the contemporary refugee determination procedure in more detail, we need to ponder the contested meaning of efficiency in refugee determinations more specifically.

Since the creation of the IRB, refugee advocates and conservative immigration critics alike have repeatedly criticized Canada's refugee determination procedure for being "too slow" in two critical respects - determining status and removing rejected claimants. The longer the whole assessment process takes, refugee advocates argue, the longer refugees remain in "legal limbo" - i.e. the longer they must wait to, among other things: enter the labour market (depending on the country making the determination - in Canada refugees can apply for a work permit fairly early - after filling out a "personal information form"), reunite with (or sponsor) their family, travel and vote, obtain permanent resident status and eventually citizenship, plus integrate more generally. While refugee advocates have raised all these points and more in debate, they have generally been reluctant to use the lan-

\footnotetext{
44. It is important to note that advanced industrialized countries only receive a small portion of the worldwide share of refugees.

45. James HathaWAY, The Rights of Refugees under International Law, Cambridge: Cambridge University Press, 2005.

46. See Ninette KeLLEY and Michael TREBILCOCK, The Making of the Mosaic: A History of Canada's Immigration Policy, Toronto: University of Toronto Press, 1998.
} 
guage of efficiency when discussing the refugee determination process. ${ }^{47}$ They have been equally reluctant to spell out "ideal" time-lines for the processing of claims, even when criticizing government proposals that explicitly introduce such.

Conservative critics of the refugee determination process, on the other hand, have extensively used the language of efficiency in demanding more government efforts to "manage" and "control" migration in the "national interest" (which is often left undefined). They have argued, among other things, that extended time spent in the "system", with its "virtually endless opportunities for review and delay", 48 inevitably leads to abuse in that it attracts fraudulent claimants who use their time to gain a foothold in Canada and who will eventually disappear underground, which is even more worrisome since the events of 9/11. Stephen Gallagher further argues that the IRB's quasi-judicial decision-making process and the independence of its decision makers is an outlier among OECD countries and at the heart of Canada's "broken" refugee determination system. 49

All in all, the term "efficiency" in refugee determinations is primarily associated with notions of speed - i.e. the length of time it takes to assess someone's claim for refugee status or in the end, to deport him or her from Canada - but also with clear normative ideals of il/legality and the right to belong. Beyond time, cost per decision and the overall costs of the IRB's operations are a frequently quoted efficiency measure. Moreover, as we will see later, backlogs, i.e. times when the number of new refugee claims substantially exceeds the number of cases still in need of processing, have attracted particular political controversy.

The Auditor General - an officer of Parliament (i.e. independent of the government of the day) and since 1878 charged with auditing government operations and reviewing the implementation of government policy - has been another important player in the debate over efficiency in refugee determination procedures. His or her reports have repeatedly called on the IRB to fix "inefficiencies" in its operations (in 1990 and 1992; 1997 and 2001 and 2003). ${ }^{50}$ They (in keeping with the ideals of NPM) frequently allude to an ideal of a well-functioning refugee determination "system", similar to a well-oiled "machine". The critiques of both the Auditor General and others have resulted, among other things, in: special government programs to fix backlogs, the development of detailed case management tools, operational manuals, and annual performance reports. All of these measures clearly show that the IRB has matured and, in the process, constructed a wide range of "efficiency" measures to assess its "performance" on both a case-by-case and system-wide basis.

47. But see Tim COATES and Caitlin Hayward, "The Costs of Legal Limbo for Refugees in Canada: A Preliminary Study", Refuge, 22, 2005, p. 77-87. This article calculates the economic costs for leaving refugees "in limbo". For the Canadian Council of Refugees' various responses to Bill C-31, the 2012 government bill to be discussed later on, see <http://ccrweb.ca/en/myths-and-facts-c31>.

48. Alexander Moens and Martin ColacotT, "Introduction", in ID. (eds.), Immigration Policy and the Terrorist Threat in Canada and the United States, Vancouver: Fraser Institute, 2008, p. XII.

49. Stephen Gallagher, “Canada's Broken Refugee Policy System”, in Alexander Moens and Martin COLACOTT (eds.), Immigration Policy and the Terrorist Threat in Canada and the United States, op. cit., p. 60.

50. These are just the reports that discuss the IRB. A multitude of other reports analyzed the operations of Canada's immigration programs and the government ministries in charge, Citizenship and Immigration Canada (CIC), and more recently, Canada's Border Services Agency (CBSA). 
What is wrong with these efficiency measures? First, as mentioned earlier, critics of NPM have long argued that the heightened focus on efficiency measures and performance indicators has shifted the accountability for government policy away from the government of the day (more precisely its ministers) and towards government bureaucrats. Second, although the IRB always highlights that they settle refugee claims "efficiently, fairly and in accordance with the law", 51 far fewer external measures have been constructed to assess the fairness or correctness of its decisions, all elements that would highlight effective (i.e. achieving a desired result well) and not merely efficient decision-making. The most prominent measure is the rate of IRB decisions overturned by the Federal Court. It is mentioned in every annual performance report and is the only quantitative indicator that does not relate to efficiency. ${ }^{52}$ Moreover, the IRB has developed a large library of country-specific information not to mention numerous legal handbooks to ensure uniform application of the law by all IRB members, albeit with mixed success. 53 Overall, this brief excursion into the efficiency debate in refugee determinations highlights that the IRB operates in a political environment increasingly filled with references to performance-based standards.

\section{Towards a Separate Refugee Determination Procedure}

In geographic terms, Canada is a relatively isolated country. As a result, significant numbers of "spontaneous" (i.e., uninvited) refugees did not begin arriving on Canadian soil until the mid-1970s, since it is difficult and expensive to travel to Canada from most conflict zones around the world. 54 Until the 1960s, individuals already in Canada who did not meet regular immigration requirements but who wanted to stay in the country could not raise any grounds for staying whatsoever until they were deemed to be in Canada illegally and ordered to attend a deportation hearing with the IAB. Once so deemed/ordered, they could then only raise humanitarian and compassionate grounds during their deportation hearing. Failing this, the only remaining recourse was ministerial appeal. 55 The IAB's power to hear appeals even from immigrants more generally was quite limited, i.e. only certain classes of immigrants could appeal their cases. It was further a non-judicial body, entirely dependent on the Ministry.

\footnotetext{
51. This is the language used in the Board's Annual Report year after year.

52. Some critics of NPM would find it undesirable to quantify fairness in the first place. Legally trained observers may further note that the adversarial system itself ensures fairness but, as C. Dauvergne points out, the courts have also ruled that the standards of fairness vary depending on the setting, and the IRB, after all, is only a quasi-judicial tribunal. See Catherine DAUVERGNE, Humanitarianism, Identity and Nation: Migration Laws of Canada and Australia, op. cit., p. 100.

53. See Sean ReHAAg, "Troubling Patterns in Canadian Refugee Adjudication", Ottawa Law Review, op. cit., p. 337-365.

54. See Alan NASH, International Refugee Pressure and the Canadian Public Policy Response, Ottawa: Studies in Social Policy, Institute for Research on Public Policy, 1989, appendices.

55. This first IAB was created in 1956 based on provisions in the 1952 Immigration Act.
} 
A separate refugee determination procedure had been promised in a 1966 White Paper but had not been implemented. 56 Meanwhile, the government signaled that it was willing to finally sign the 1951 Geneva Convention; however, no action was taken on this until 1969. More on point for our purposes is that thoughts about signing the Convention did not actually raise any thoughts about judicializing refugee determination procedures. The 1966 White Paper merely stated that "it may be desirable to establish a Refugee Eligibility Commission, with authority to decide whether an individual applying for asylum is entitled to refugee status." 57 Only in 1973 did the government take some first steps toward separating refugees from other rejected immigrants. It did so by establishing an ad hoc committee (with government and private-sector members) within the immigration ministry to informally assess refugee claims by individuals already in Canada before the IAB formally considered them. The 1976 Immigration Act finally granted inland refugee claimants status in law by establishing a separate immigration class for them. It also conferred official legal status on the ad hoc committee, renaming it the Refugee Status Advisory Committee (RSAC). Until the IRB was created in 1989, the RSAC was responsible for assessing all inland refugee claims. ${ }^{58}$ In these early days of Canada's inland determination procedures, the number of individuals found eligible to stay was quite small - reportedly "less than a few hundred annually" - compared to later years. 59

\section{III.1. The Judicialization of Refugee Determination Procedures}

In the mid-1960s, Canada's broader immigration policy paradigm shifted to one of equality and non-discrimination. This marked the end of the long period of statutory marginalization of the courts 60 and the beginning of the slow judicialization of refugee determination procedures. This sea change is best expressed in the government's 1966 White Paper on immigration: "For justice to be done, it must be seen to be done." 61 This was certainly a new tune for a government that had previ-

56. Gerald E. DiRKs, "A Policy within a Policy: The Identification and Admission of Refugees in Canada", Canadian Journal of Political Science, 17, 1984, p. 284.

57. Department of Manpower and Immigration, White Paper on Immigration (Ottawa, 1966), p. 23. Cited in Christopher G. ANDERSON, Restricting Rights, Losing Control: Immigrants, Refugees, Asylum Seekers, and the Regulation of Canada's Border, 1867-1988, doctoral dissertation, McGill University, 2006, p. 636.

58. See Freda Hawkins, Canada and Immigration: Public Policy and Public Concern, Montreal (QUE): McGill-Queen's University Press, 1972, and Gerald E. DiRKs, Controversy and Complexity: Canadian Immigration Policy During the 1980s, Montreal, Kingston: McGill-Queen's University Press, 1995.

59. No official statistics were kept at the time. For these figures, see Gerarld E. Dirks, Controversy and Complexity: Canadian Immigration Policy During the 1980s, op. cit., p. 289.

60. Between 1910 and 1967, Canadian courts were officially barred from reviewing immigration (including deportation) proceedings through a privative clause. However, this did not entirely preclude them from reviewing immigration matters. See Dagmar SoENNECKEN, "Extending Hospitality: History, Courts and the Executive”, Studies in Law, Politics and Society, 60, 2013, p. 85-109.

61. Department of Manpower and Immigration, White Paper on Immigration (Ottawa, 1966), p. 33-34. Cited in Christopher G. ANDERSON, Restricting Rights, Losing Control: Immigrants, Refugees, Asylum Seekers, and the Regulation of Canada's Border, 1867-1988, op. cit. p. 637. This quote is a paraphrase of Lord Hewart, from Rex $v$ Sussex Justices: Ex parte McCarthy [1924] 1 KB 256 at 259, who said "that justice should not only be done, but should manifestly and undoubtedly be seen to be done". Thanks to Matthew Kudelka for this. 
ously declared immigration a privilege and not a right. ${ }^{62}$ Until this point in time, ideas such as non-citizens' rights and access to justice were nowhere to be found in the field of immigration. The Immigration Appeal Board (IAB) Act of 1967 was of central importance in this shift. In it, the government not only transformed the first IAB into a court of record, but also allowed for an appeal to the Supreme Court of Canada (with leave) on questions of law. 63 For potential deportees at the time which would have included anyone claiming refugee status in Canada at the time (since individuals claiming refugee status did not have official status in law until 1976) - this reform was indeed a great advance. While this change was a first step towards a judicialized procedure, it came about without the courts needing to "nag" Parliament to do it.

In the absence of a comprehensive immigration reform bill (which would not come for a number of years), the IAB Act became the focal point for what Freda Hawkins has called a "high caliber debate on the state of immigration in Canada". The debate was rich with references to the importance of justice, law, and the courts. It was remarkable, as well, because parliamentarians across party lines highlighted the importance of "building up a body of jurisprudence in the field of immigration practice" and of having an "impartial" board with "respected barristers". 64 There was also plenty of debate about the scope of the rights and appeal options that non-citizens - in particular, sponsors - ought to be granted. National security was key to this debate. However, the opposition failed in its attempts to allow individuals to appeal who had been refused entry to Canada on national security grounds. 65 The immigration minister, Jean Marchand, concluded that all in all, the new procedures should comply with the basic principles of "elementary justice". 66 The debate suggests that bureaucrats and parliamentarians had arrived at a point where the lack of jurisprudence and at least quasi-judicial procedures were considered a significant problem from both a theoretical and a practical perspective.

The all-party debate also made it clear that for all the lofty talk about rights and justice, a driving force on this matter was that the Immigration Department - and the minister himself - were drowning in cases and needed serious help. Since so much under the old legislation had been left to discretion, many immigration cases

62. The 1966 Sedwick Report that called for numerous rights for non-citizens and a judicialization of immigration and refugee determination procedures, also affirmed that immigration was not a right. Ibid., p. 631. Certainly, Canada's international reputation also played a role in this process. See Triadafilos TriadAfiLopoulos, "Global Norms, Domestic Institutions and the Transformation of Immigration Policy in Canada and the US”, Review of International Studies, 36, 2010, p. 169-194.

63. The newly transformed IAB could quash deportation orders and authorize the landing of deserving individuals on humanitarian grounds, in particular if the deportees faced persecution in their country of origin. Still, the Minister retained substantial discretionary powers. See Ninette KELLEY and Michael TREBILCOCK, The Making of the Mosaic: A History of Canada's Immigration Policy, op. cit., p. 368.

64. The Chair of the IAB, Janet Scott, also commented on the importance of creating precedents in immigration law (of which there was little at the time) before the Special Joint Committee in 1968. See Freda HawkIns, Canada and Immigration: Public Policy and Public Concern, Montreal: McGill-Queen's University Press, $2^{\text {nd }}$ ed., 1988, p. 165-166.

65. Ibid., p. 164.

66. Cited in Christopher G. ANDERSON, Restricting Rights, Losing Control: Immigrants, Refugees, Asylum Seekers, and the Regulation of Canada's Border, 1867-1988, op. cit., p. 634. 
were floating all the way up to the minister's office. ${ }^{67}$ In short, discretionary decision-making had become highly inefficient. The IAB was heavily overburdened - a situation that only grew worse after the 1967 reforms. The minister would eventually be removed as the final authority and the IAB would be empowered and judicialized. This would serve to overhaul and clarify the old procedures; most importantly, it would take some pressure off the ministry. So went the thinking among government officials. 68

This "great leap forward" in the judicialization of immigration affected refugee claimants as well. In theory, immigration appeal procedures were open to refugee claimants; in practice, those claimants rarely took this course, since their treatment was even more arbitrary than it was for "normal" deportees. To begin with, at the time (i.e., before 1976), a refugee claim did not automatically trigger legal status. Such a claim could only be made at an inquiry conducted by an immigration officer after the individual had been declared illegally in Canada (e.g., because a visa had expired) and after the government threatened deportation. Second, even the ad hoc committee instituted in 1973 to screen refugee applications possessed no status in law. Since it was ad hoc and thus informal, refugee claimants had no right to appear before it in person, and if a claim was denied, the claimant was not told why. Furthermore, appeal to the IAB was not a right; it required the board's permission, which was only granted if the claim was likely to succeed. 69

Only after the 1976 Immigration Act was passed were refugee claimants given official legal status. Only then were informal refugee determination procedures enshrined in law; only then was the RSAC acknowledged as the official decisionmaking body for refugee claims. Note that the RSAC's procedures were further shifting toward the quasi-judicial, in that they blended judicial with administrative procedures. As legal scholar Julius Grey noted, several rules resembling judicial procedure were already present then. ${ }^{70}$ Claimants had a right to counsel during their meeting with the senior immigration officer (SIO) who performed the initial interview; they received a copy of the transcript of their meeting with the SIO, which was forwarded to the RSAC; and they were entitled to translation services. Rejected refugee claimants also had a right to a "redetermination" hearing before the IAB, though the board had to find the appeal credible; in addition, further access to the courts was possible. Also, the RSAC board was enlarged to include private citizens appointed by the minister (a precursor to today's procedure). ${ }^{71}$ And the RSAC was provided with more detailed guidelines for assessing claims. Finally,

67. See also ibid., p. $628 \mathrm{ff}$.

68. Aside from the Minister of Immigration at the time (Jean Marchand), three former Ministers of Immigration spoke. The bill was debated by the "committee of the whole", i.e. by the entire house, at second reading. See Canada, HCD, Feb 20 to $23^{\text {rd }} 1967$. It received $3^{\text {rd }}$ and final reading on March $1^{\text {st }}$ of the same year. See Freda Hawkins, Canada and Immigration: Public Policy and Public Concern, op. cit., p. 163.

69. Gerald E. DiRKs, "A Policy within a Policy: The Identification and Admission of Refugees in Canada", op. cit., p. 290.

70. Julius GREY, Immigration Law in Canada, Toronto: Butterworths, 1984.

71. Gerald E. DiRKs, "A Policy within a Policy: The Identification and Admission of Refugees in Canada", op. cit., p. 78. 
for the first time, a UNHCR observer was allowed to sit in on the RSAC's deliberations. Still, human rights advocates of the day harshly criticized the procedures for not being good enough.

\section{III.2. Prelude to Singh and the Creation of the IRB}

Criticism of the (then) new refugee admission procedures peaked during the late 1970s and 1980s. The debate highlighted a gap between demands for administrative efficiency (advocated by the immigration bureaucracy) and those for increasing procedural justice (advocated by refugee advocates). ${ }^{72}$ Central to these criticisms was that refugee claimants were not allowed to appear before the RSAC in person. In addition, the ministry still did not have to give its reasons for rejecting claims, though (as Gray points out) the involvement of the Federal Court practically forced the minister to offer at least perfunctory reasons. ${ }^{33}$ Many government commissions studied the matter and suggested changes. Most of those studies recommended that the government restructure the procedure to improve the standards of procedural justice. ${ }^{74}$ According to some observers, the courts were already pushing the system in that direction. As Ed Ratushny argued in a 1984 study of refugee determination procedures (commissioned by the government), Canadian courts tended to follow British tradition and impose higher procedural standards on decision-making bodies if the choices before the administrator were "adjudicative" rather than "administrative". Following this logic, they had begun to demand from the RSAC and the IAB a standard of fairness beyond the rules of natural justice (and this was before the Charter). ${ }^{75}$

The government was still not willing to amend the procedure. Oral hearings took too much time and cost too much money. In the view of the bureaucrats, backlogs were inevitable. Small pilot projects on oral hearings were instituted "to avoid legal challenges", as one observer noted; but these were discontinued soon after. 76 The Supreme Court of Canada ended this debate in the spring of 1985 in the Singh case. The Court ruled that refugee claimants physically present in Canada were entitled to the protection of the 1982 Charter of Rights and Freedoms. Thus the refugee determination procedures would have to comply with the standards of fundamental justice set out in Section 7 of the Charter. These included the right to an oral hearing. 77

\footnotetext{
72. Critical voices came from Non-governmental organizations (NGOs), in particular the churches and Amnesty International, Parliamentarians and authors of numerous reports. See ibid., p. 81.

73. Julius GREY, Immigration Law in Canada, op. cit., p. 112.

74. See also Gerald E. DiRKs, "A Policy within a Policy: The Identification and Admission of Refugees in Canada", op.cit., p. 80, and Alan NASH, International Refugee Pressure and the Canadian Public Policy Response, op. cit., p. $45 \mathrm{ff}$.

75. Ed Ratushny, A New Refugee Status Determination Procedure for Canada. Report to the Hon. John Roberts, Minister of Employment and Immigration, Ottawa: University of Ottawa, 1984, p. 34.

76. Alan NASH, International Refugee Pressure and the Canadian Public Policy Response, op. cit., p. $45 \mathrm{ff}$.

77. See Singh. S. 7 of the Charter states: "everyone has the right to life, liberty and security of the person and the right to not be deprived thereof except in accordance with the principles of fundamental justice".
} 
Then the government stalled. As Ian Greene reports, the ministry was shocked: it "had been totally unprepared for the Supreme Court ruling: 78 Considering all the studies the government had conducted prior to Singh, this is surprising. By the time the government introduced reform legislation (first allowing for an expansion of the IAB in 1987), a substantial backlog had developed. In the end the entire procedure was revamped and the IRB was established in 1989, over considerable controversy. ${ }^{79}$ The new decision-making body, the IRB, was generally judged more efficient than its predecessor, as its speed and acceptance rates were initially higher. But its establishment was also an important step toward the judicialization of refugee determinations, which later began to draw fire. 80

Strangely, the 1989 reforms did not include access to a substantive redetermination, even though failed refugee claimants had access to a substantive reassessment of their claim before the 1967 IAB. ${ }^{81}$ The possibility of a substantive redetermination is still absent from today's procedure in 2012, although the latest government reform bill (Bill C-31), has promised to finally implement it, albeit it, as I will discuss later, at considerable cost. Such a possibility for redetermination has been a long time coming. It was first formally promised with legislative reforms in 2001, but in 2002, the government delayed the implementation of the Refugee Appeals Division (RAD) indefinitely for fear of creating a backlog and attracting more unfounded claims. ${ }^{2}$ In 2005, it further declared that the lack of an appeal on the merits was not inconsistent with its domestic and international obligations to refugees.

\section{III.3. Reforming the 1989 Landmark}

Since the creation of the IRB in 1989, there have been two major reforms to Canada's immigration and refugee procedures. A third is currently underway. The first, the 1992-93 reform, is typically billed as a fine-tuning of the 1989 reforms that initially established the IRB, since it eliminated the "credible hearing" stage of the refugee determination procedure, which by most observers was judged redundant, since most refugees passed it easily. 83 The second, the 2001-2 reforms, are usually

78. Ian GREENE, The Charter of Rights, Toronto: Lorimer, 1989, p. 133.

79. Indeed, the Canadian Council of Churches launched a legal challenge immediately after the new act came into force. Canadian Council of Churches $v$. Canada (Minister of Employment and Immigration) [1992] 1 SCR 236.

80. Gerald E. DiRKs, "A Policy within a Policy: The Identification and Admission of Refugees in Canada", op. cit., p. 95. He states that the RSAC's acceptance rate averaged 25 percent while the IRB averaged 76 percent in 1989. For more details on acceptance rates prior to 1989, broken down by category, see also Alan NASH, International Refugee Pressure and the Canadian Public Policy Response, op. cit., p. 53.

81. The Senate Report on Bill C-55 in 1988 (which would establish the IRB and become the new Immigration Act in 1989) recommended the Federal Court be given the power to review the facts of each case but this recommendation was not taken up. See Alan NASH, International Refugee Pressure and the Canadian Public Policy Response, op. cit., p. 57.

82. The refugee NGO community supported another feature of the IRPA (the reduction of the number of decision-makers at the IRB from two to one) only in exchange for the government's assurance that failed refugee claimants would finally have access to an appeal on the merits. For the official government announcement see <http://www.cic.gc.ca/english/refugees/rad-menu.html>.

83. When the Board was founded in 1989, an immigration officer had to conduct a credibility assessment before the case could be heard by the IRB. Along with this assessment, the government also eliminated a 
read as a part of Canada's response to the war on terror. Although this is certainly true, both also brought with them an important shift in the judicialization trend just detailed. While judicialization was briefly seen as a possible cure to bureaucratic inefficiency in the 1960s, by the time the IRB was established, the tone had shifted. As I discussed earlier, although the IRB was initially hailed as quite efficient, with the help of numerous Auditor General Reports among others, it eventually became branded as highly inefficient. What is more, a judicialized refugee determination procedure together with access to the courts was slowly judged not merely inefficient but highly undesirable by some observers.

The 1992-93 reforms contained a few indicators of this changing tone. First, they reorganized the Federal Court Act, shuffling responsibility for reviewing IRB decisions from that court's Appeal Division, which some considered quite "activist" or "interventionist", to the Trial Division. ${ }^{84}$ Second, they reduced the number of judges hearing a case at the Federal Court from three to one. Third, they introduced a "certification" requirement, which made an appeal from the Trial to the Appeal Division of the Federal Court subject to the requirement that the Trial judge certify, at the time of rendering judgment, that the case involved a serious question of general importance. Although these particular measures could also be read as empowering the courts (which were actually considered conservative by seasoned observers), 85 they still make clear that the government was intent on reducing access to them.

But just because dissatisfaction with the existing procedures was growing, this did not mean that the public or the government of the day was ready to completely abandon the IRB or a judicialized procedure yet. This could clearly be observed on a number of occasions, for instance after the tabling of a controversial governmentcommissioned review of Canada's immigration system in 1997, Not Just Numbers, that proposed a radical overhaul of the system, including the amalgamation of Canada's overseas unit for assessing refugee claimants with the inland unit, thus forming a new protection agency staffed entirely by civil servants, though officers in the new review branch would supposedly be assured independence. 86 Throughout the report, the guiding rationale was efficiency, speed and better alignment with Canada's national interest, which was largely described in economic terms. The report caused "a storm of controversy", leading the Minister in charge to eventually distance herself from it. 87

\footnotetext{
federally funded "designated counsel" program, which provided all refugee claimants with legal counsel free of charge. For more, see AUdITOR GENERAL OF CANADA, "Immigration - Refugees", in 1990 Report of the Auditor General of Canada, Ottawa: Auditor General of Canada, 1990.

84. See Mary C. Hurley, "Principles, Practices, Fragile Promises: Judicial Review of Refugee Determination Decisions before the Federal Court of Canada”, McGill Law Journal, 41, 1996, p. 317 ff, Julius GREY, Immigration Law in Canada, op. cit., p. 116.

85. Ninette KeLleY and Michael TreBILCOCK, The Making of the Mosaic: A History of Canada's Immigration Policy, op. cit., p. 417.

86. See Immigration Legislative Review, Not Just Numbers: A Canadian Framework for Future Immigration, Ottawa: Minister of Public Works and Government Services Canada, 1997, p. $77 \mathrm{ff}$.

87. Ninette Kelley and Michael TREBILCOCK, The Making of the Mosaic: A History of Canada's Immigration Policy, op. cit., p. 420.
} 
The second major reform since the creation of the IRB in 1989 was the passing of the Immigration and Refugee Protection Act (IRPA) in 2001. This act replaced the 1976 Immigration Act. At roughly the same time, the government passed the AntiTerrorism Act (Bill C-36 or ATA), which is also relevant to refugee determination processes, if only, as Audrey Macklin put it, because it has expanded "state practices that marginalize and stigmatise through heightened surveillance, harassment, ethnic profiling, and the like". ${ }^{8}$ Simultaneously, the government implemented the Safe Third Country Agreement (STCA) with the United States, which had been in the works since the 1980s. 89 Also in 2002, the Supreme Court handed down two important rulings relating to refugees and national security, Suresh and Ahani. 90

While these two major reforms clearly underscore the growing securitization of immigration and refugee matters, the security focus was paired with a continued effort to reduce access to the courts and, much more explicitly, the refugee determination procedure itself. First, IRPA expands the grounds of ineligibility to file a refugee claim mainly to include reasons of national security. It also eliminated appeals for such individuals and denies them access to the pre-removal assessment procedure (PRRA), which is administered through the Ministry (i.e. not through the IRB), although their case will still be reviewed with Canada's obligations under the International Convention against Torture in mind. All in all, while the government argued that the overall standard of protection for failed refugee claimants who are clear of national security concerns had been expanded, the act removed many critical details from Parliamentary scrutiny and delegated them to the Executive, returning the governance of immigration back to what is was in previous decades. 91

But what about efficiency? While these reforms clearly tried to stem the judicialization trend, their focus on efficiency was equally significant. The elimination of the credible basis hearing stage, central to the 1992-93 reforms, came in the wake of the 1990 Auditor General's report blasting the government's handling of a substantial backlog of cases that dated back to before the creation of the IRB. The second, 2001 reforms were driven by efforts to increase the efficiency of the refugee determination system by limiting access to genuine claimants while keeping out fraudulent and dangerous ones. The government's backpedaling on implementing a substantial redetermination procedure was also motivated by fears of being flooded with fraudulent claims.

88. Audrey MaCKLIN, “Borderline Security”, in Ronald J. DANIELS, Patrick MACKLEM, and Kent RoACH (eds.), The Security of Freedom: Essays on Canada's Anti-Terrorism Bill, op. cit., p. 298. The ATA underwent a first, mandatory Parliamentary review three years after its enactment. For a critical assessment see Kent ROACH, "Better Late Than Never? The Canadian Parliamentary Review of the Anti-Terrorism Act", IRPP: Choices, 13, September 2007, p. 1-38.

89. Canada and the United States signed the "Safe Third Country Agreement" on Dec 5, 2002.

90. Suresh v. Canada (Minister of Citizenship and Immigration) 2002 SCC 1, Ahani v. Canada (Minister of Citizenship and Immigration) 2002 SCC 2.

91. See Estibalitz JIMENEZ and Francois CRÉPEAU, “The Immigration and Refugee Protection Act”, Horizons: Policy Research Initiative, p. 18-20. 
Building on a reform commenced in 2010 (when the current government of the day was already in power, albeit with minority status), 92 the latest refugee determination reforms in 2012 take efficiency to a new height by taking a page from a number of European countries, notably Germany, and, for the first time in legislation (or more precisely, in regulations accompanying it), spelling out detailed timelines for the processing of refugee claims. Both reforms have naturally generated considerable debate and controversy. These latest reforms further signaled a still forthcoming shake up to the nature of decision-making before the IRB. However, most of its procedural changes have not been implemented yet. Bill C-11 mandated that all decision-makers at the IRB become public servants rather than being appointed. It also introduced new processing deadlines for "manifestly unfounded" claims and for those from "designated countries of origin", a new categories in Canadian law and reduced their access to an appeal. And lastly, the Act promised to finally implement a refugee appeal division within the IRB promised since 2002. However, appeals must be filed within such a tight timeline (15 days) that most refugee advocates have declared it completely unworkable. ${ }^{93}$

\section{Conclusion}

Lauren Edelman's body of work on "the managerialization of law" has provided us with a number of critical insights into the operation of law in private organizations. Her detailed analysis of the workings of diversity law in private enterprises in particular has demonstrated that "the managerialization of law has both costs and benefits for legal ideas." 94 While the managerialized version of anti-discrimination law became successful by transforming narrow legal redress categories into a broader vision of diversity management, this repositioning came at a price namely the mollification of any claims to redressing historical disadvantage in the name of higher social justice ideals. All in all, Edelman is not so much interested in offering a critique of this transformation as she is in first uncovering its detailed workings.

This paper has argued that Edelman's important work on the managerialization process within organizations needs to be complimented by a focus on the managerialization from without, which I have defined as the explicit introduction, by political actors, of managerial ideals into an organizational setting which they did not previously dominate - in this case, the running of government. In particular, I have been detailing the gradual managerialization of refugee determinations, a setting where legal ideas of fairness and justice seem of particular importance. I do not

92. Bill C-31, the Protecting Canada's Immigration System Act, received Royal Assent on June 28, 2012. A number of other, related bills were already passed by the same government a few years. Chiefly among them is Bill C-11, the Balanced Refugee Reform Act, which received Royal Assent on June 29, 2010.

93. For critical assessments, see for example the Canadian Council of Refugees website at <http://ccrweb.ca/ en/comments-c-11-regulatory-amendments> or Amnesty International's at <http://www.amnesty.ca/blog post.php?id=3406>.

94. Lauren Edelman, Sally Riggs Fuller and Iona MARA-Drita, "Diversity Rhetoric and the Managerialization of Law", op. cit., p. 1632. 
mean to suggest, that the rise of NPM in Canada was the reason for the managerialization of refugee determinations that I have detailed. In fact, my "zoomed out" analysis shows that managerial ideas, in particular efficiency concerns, were already powerfully present prior to the rise of NPM in the 1990s, albeit associated with traditional themes of Executive governance, such as administrative control and ministerial discretion. Rather than focusing on establishing causality, my goal, like L. Edelman's, is to uncover the way in which political actors have used managerial ideas, chief among them efficiency, for retaining control over refugee determinations, in light of another powerful trend that seems to threaten this control - the judicialization of refugee determinations.

In sum, in the mid 1960s, an overburdened IAB broke new ground by opening the door to gradually judicializing Canada's refugee determination procedure. At the time, a process that followed at least "elementary justice" principles and access to the courts was considered not only internationally more popular but also more efficient. However, the efficiency pendulum quickly swung back to be onside with those favouring administrative discretion over a further expansion of procedural justice. Justice (in this case, oral hearings) was now considered too costly. Although many considered the 1985 Singh case and the subsequent creation of the IRB in 1989 a definite victory of procedural justice over administrative convenience, the victory came with a cost. As the institution matured and NPM became more popular within the Canadian government, more and more efficiency measures were constructed. Although the IRB met the performance goals associated with these measures during numerous years, 95 perceptions of the IRB as "creaky, leaky" and generally inefficient began to dominate from then onwards. At the same time, access to the courts for refugees also became problematic and even suspect.

While the state ultimately retreats from being an agent that gives meaning to law in favour of managerial professionals, Edelman, in her analysis, clearly acknowledges that managerial ideas and rhetorics do not evolve in a vacuum. 96 Bringing the "state back in", as my analysis does here, helps us uncover their evolution and changing allegiances. Ideas and rhetorics do not exist detached from political values and agendas. As we have seen, both legal and managerial ideas can be mobilized by political actors for their purposes; at times together, at times against each other. While this analysis has highlighted the interplay between efficiency and judicialization, these were of course not the only ideas that drove the development of the refugee determination procedure. Others, notably notions relating to security and national identity have always been equally important and, at times, were aligned with legal or managerial ideas.

As Kitty Calavita recently noted, "for much of the last century", the US agency charged with immigration enforcement has faced constant criticism regardless of the many reforms it underwent. She concludes that the agency is in a "damned if they do, dammed if they don't" position because it "has the misfortune of sitting at

95. This can quickly be established by surveying the Board's Annual Reports over the years.

96. Lauren Edelman, "The Legal Lives of Private Organizations", op. cit., p. 245, Lauren Edelman, Sally Riggs FulLER and Iona MARA-DrITA, “Diversity Rhetoric and the Managerialization of Law”, op. cit., p. 1627. 
the fault line of a structural contradiction between the economic demand for cheap immigration labour and political demands for border control". ${ }^{97}$ I would argue that the IRB and its predecessors sit on a similar fault line, with the difference that theirs is buried underneath a "justice and fairness" layer. Since Canada is a country of immigration, it has retained a strong tendency of wanting to select all of its immigrants, even those claiming humanitarian protection. This legacy has made it difficult to fully integrate legal norms of fairness and procedural justice into its admission procedures, be they international or domestic, because they can take away some of that control. So whatever reforms the IRB or its successors undergo, they will never be considered good enough unless the state is willing to give up some of that control or shift its way of thinking in such a way that upholding legal ideals is efficient (and ultimately effective) way of governance once again.

\section{- L'auteur}

Dagmar Soennecken est professeure adjointe à la School of Public Policy de York University (Canada). Spécialiste de la politique comparée et des politiques publiques dans l'Union Européenne et en Amérique du Nord, ses projets de recherche s'intéressent au droit et aux tribunaux dans le domaine de la citoyenneté et de l'immigration. Parmi ses publications :

— «Extending Hospitality? History, Courts and the Executive», Studies in Law, Politics and Society (special issue, ed. Austin Sarat, "Who belongs? Immigration, Citizenship and the Constitution of Legality "), 60, 2013 ;

- «The Growing Influence of the Courts over the Fate of Refugees", Review of European and Russian Affairs, 4 (2), 2008.

97. Kitty CaLAVITA, Invitation to Law \& Society, op. cit. p. 102. 